\title{
Unboxing "Born-frees": freedom to choose identities
}

Saloshna Vandeyar ${ }^{a}$

\section{Abstract}

This qualitative case study sets out to explore how "born-free" students constitute, negotiate and represent their identities in South African schools twenty years after the advent of democracy. The meta-theoretical paradigm of social constructivism and the methodology of narrative inquiry was used. Data comprised a mix of semi-structured interviews and field notes. Inductive thematic analysis was used to analyse the data. Findings reveal that the demographic diversity of "born-free" students seemed to extend towards many competing views of identity. "Born-free" students did not possess distinctive views about their generations" identity. Racial identity still seemed to play a pivotal role. Some "born free" students expressed optimism with the freedom their identity provided, while others felt constrained by the enduring historical legacy of apartheid, transmitted through knowledge in the blood. Although "born-free" students themselves did not live through apartheid, the physical legacies of apartheid -such as its geographical contours - served as a daily reminder of its presence. "Born-free" students are not only well aware of the social and political dynamics of the country, but are also beginning to question externally imposed identities.

Keywords: "Born-free" students. Geographical contours. Historical legacy. Identity. Knowledge in the blood. Youth justice.

\section{Introduction}

Captured by the euphoria of a South African utopia, post-1994 witnessed the coining of terms like "Rainbow Nation" and "born-free". These terms have been used to describe post-apartheid South Africa over the past two decades: "as in, we apparently have been living in, and now live in, a 'Rainbow Nation' where 'born-frees' run wild and free" (CAWE, 2014), possess the inherent ability and are obligated to change society for the better. In South Africa, the concept "born-free" refers to a person who was born or grew up after the end

a Faculty of Education, University of Pretoria,Groenkloof Campus, Pretoria, South Africa

Recebido em: 13 fev. 2019

Aceito em: 09 mai. 2019 
of the apartheid era. This concept however, does not originate from the youth themselves (MAIMELA, 2014). Its origins stem from the South African media and it is craftily appropriated by various interests in society in the course of the battle of ideas, jostling to shape society in their own image (MAIMELA, 2014). In a democratic South Africa, youth have the right to cultural freedom that enables them to define themselves.

Almost all countries in the world face the daunting task of managing diversity. South Africa is no different. During the apartheid era, people were categorised and placed into neat little boxes namely, white, Indian, Coloured and African, with no room for deaggregation within each of these categories. The advent of democracy witnessed the mass entry of "black" immigrants into South Africa, which for a brief moment created quite a stir, given the South African psyche, as this was a new "breed" that did not neatly fit into any of the existing boxes. Almost instantaneously a new box namely "the makwerekwere" was created to solve this problem. Aligned ironically with the apartheid ideology of categorisation, the media coined the term "born-free", meaning those who have no living memory of apartheid and refers to a specific generation of South Africans born after 1990, regardless of race, income, or ethnicity. Given the complexities of the South African context, how then do these South African youth identify? Do they identify as "born-frees", and if so why and if not why not? Accordingly, this study asks how do "born-free" students constitute, negotiate and represent their identity twenty years after democracy in South Africa.

\section{Theorizing Identity}

A brief history of the theoretical field of identity illustrates how studies began from the notion of groups and developed to that of identity. As early as 1961, Wirth claimed that ethnic distinctions are based on power relations and therefore on inequality between dominant and minority social groups. Glazer and Moyniham (1963) saw ethnic groups as interest groups, emphasizing political aspects in them. Ethnicity was seen as a subjective process of identifying a group in which people use ethnic labels to define themselves and their interaction with other groups (BARTH, 1969). Cohen (1978) advocated for the concept of situational identity, arguing that the question of the salience of ethnic identity should be understood and accepted as involving a subject or a characteristic considered important in a given social situation. He claimed that identities of members and categorizations by others is more or less fluid, more or less multiple, forming hierarchies of dichotomizations us/them (COHEN, 1978). 
It was from this theoretical framework that ensuing studies began to adopt the concept of identity, instead of a group, in order to study the phenomenon of ethnicity. The nature of ethnic identity, as it would persist, change or disappear among other forms of identity begun to be explored (EPSTEIN, 1978). Ethnic identity came to be understood as a psychosocial process, neither given nor innate, but constructed, involving a certain amount of choice on the part of individuals, from their analyses in the face of social coercion (EPSTEIN 1978). Okamura (1981) proposed the concept of situational ethnicity that afforded individuals the option of assuming either their primary ethnic identity or other social identities such as class or occupation. This offered the possibility for the manipulation of a constructed identity (OLIVEIRA, 1976). According to Oliveira (1976) the concept of ethnic group would not account for the persistence of ethnic identification of people and groups. He claimed that in assuming an ethnic category individuals occupy a particular place in the system of relations and, therefore, exercise a certain social status (OLIVEIRA, 1976). The difference, however, would lie in the fact that, while status and roles would fragment the person, identity would essentially be a synthesis concept, representing "the process by which the person integrates his various statuses and roles, as well as his various experiences in a coherent image of itself" (EPSTEIN, 1978, p. 100). "Variability is the essence of ethnicity in its importance for structuring social relations in diverse situational contexts" (BARTH, 1981, p. 463).

Researchers' interest in identity developed from Erikson's (1968) seminal work and opened debates on the meaning of identity (FEARON, 1999; MARCIA, 1980; YUVAL-DAVIS, 2010), ethnic identity (PHINNEY et al., 2001; YIP, 2018), identity and immigrant students (SCHWARTZ et al., 2017; SUAREZ-OROZCO; SUAREZ-OROZCO, 2008; VANDEYAR, 2010), identity and acculturation (BERRY et al., 2006; COHEN, 2004), cultural identity (FORSYTH, 2018; JENSEN, 2003), and personal and social identities (BRIEGER, 2018; STETS; BURKE, 2000; TAJFEL, 2010). Identity is therefore used by scholars in varied ways and contexts to emphasise different facets of human self-definition (ONORATO; TURNER, 2004). Identity is an important aspect in the development of an individual, as it is a new way of thinking about oneself that becomes pronounced during adolescence (MEEUS et al., 1999) and when firmly developed, it provides a sense of belonging and uniqueness to an individual.

A review of the voluminous literature reveals that identity construction is an ongoing process, which does not unfold neatly, but involves a commitment to a social orientation, an ideological stance, and a vocational direction (MARCIA, 1980). This suggests that identity choice varies within individuals across time, and is influenced by the characteristics of the individual and the context. 
Marcia (1980, p. 159) claims that identity is "an internal self- constructed, dynamic organisation of drives, abilities, beliefs and individual history", which facilitates psychological differentiation from others. The construction of an identity "follows a hierarchical sequence" (MARCIA, 1966; 1980, p. 111) in which all youth move steadily from a stage of ethnic or "racial unawareness" to one of "exploration" to a final stage of an "achieved" sense of racial or ethnic identity. Parham (1989) argues that the process of identity formation is a "spiralling" back to revisit previous stages, each time from a different vantage point. According to Hall (1996a; 1996b), identity is something that is produced and created from the ingredients of a personal past but is always in a process of transformation. The focus of identity formation is on becoming rather than being and is subject to how one is positioned by and positions oneself with respect to the past. Hall (1993) claims that identities are never complete; they are never finished concepts, and that they are always in the process of formation. Thus, the notion of what identity to see with "people who look", "feel the same" or "call themselves by the same name", does not make the same sense anymore. Because, like a process, as a narrative or as a discourse, "identity is always viewed from the perspective of the other" (HALL, 1993, p. 49). Identity is always influenced by culture, history, and power and refers to "a process located in the core of the individual and yet, also in the core of his communal culture" (ERIKSON, 1968, p. 22).

Drawing from Erikson's view, Israelite, Oliver and Goldstein (2002, p. 134) define identity as a "complex, multi-layered, multifaceted social construction that is a product of a wide range of societal and cultural forces". This definition implies that forming an identity, whether a personal or social one, is not a simple task, as it involves negotiating it from complex cultural and societal forces. As a result of the dynamic character of the social world, identity cannot be said to be a fixed phenomenon, rather it is a contemporary context-driven and evolving set of constructions (ALVESSON, ASCHCRAFT; THOMAS, 2008). Consequently, identity consists of a range of markers, such as race, gender, age, ethnicity, and religion, all of which play a role in assisting the individual to determine who they are, what they believe in and how they claim membership to their society. Identity represents the intersection of the individual and society (YIP, 2008), which means an individual plots a sense of self from what the society provides at a particular time. Identity is shaped by daily interactions and practices that are characteristic of the social context, and does not have a fixed end. Teixeira $(2018$, p. 1) argues that "we must recognize ethnic and racial identities as cultural phenomena that are susceptible to change, which drives us to continue the discussion, trying to capture the meaning of these transformations". 
In the process of identity construction, adolescents go through "identity crises" (ERIKSON, 1968; MARCIA, 1980), which involves engaging in an intensive analysis and exploration of different ways of looking at oneself (MEEUS et al., 1999). According to Erikson's stages of psychosocial development, the emergence of identity crises means the adolescent struggles between feelings of identity and role confusion, and to move out of the crises, the individual needs to commit to a particular identity, which is not an easy task. It becomes a difficult task because it involves reconciling the identity imposed upon oneself by the family and society with one's need to assert control and seek out an identity that creates a sense of satisfaction, uniqueness, as well as feelings of competency (FRENCH et al., 2006). Resolving an identity crisis becomes more complex as it goes beyond exploring possible selves and finding ways of attaining these selves; it involves negotiating other identities, such as ethnic and cultural identities, and doing so in the social context. Jensen (2003) claims that as diverse ethnic and cultural groups come into contact with one another, there are invariably differences in power and status among these groups, making identity formation a complex activity for adolescents.

Identity can thus be depicted as multiple and shifting notions of self that are largely shaped by daily interactions and practices, and plays out in multiple identities such as personal, racial, ethnic, social and cultural.

\section{Theoretical framework: Ecological model of racial identity development}

Ethnic identities are not given, fixed, or unchanging, but are continually evolving products of material and social circumstances and of the actions of groups themselves, wrestling with, interpreting, and responding to those circumstances, building or transforming identities in the process (CORNWELL, 2000). When ecological models incorporate historical, geographical, and gender lenses, then identity - both racial and ethnic - will always be in flux because identities are dynamic. In this study I will use the ecological model of racial identity development (ROOT, 2003) to guide my process of inquiry, as this model takes into account the following factors, which may affect the identity construction of participants, namely, the contextual macrolenses of gender, class, and regional history of race with which to filter the meanings of situations and experiences to which people are exposed; the microlenses of inherited influences (for example, given names, languages spoken in the home, phenotype, cultural values, sexual orientation), traits (for example, temperament, talents, coping skills), and social environments (for example, home, school, work) which also filter the meaning of daily experiences (ROOT, 1998). This ecological framework for identity 
development not only explains the different ways in which people come to identify themselves but it also allows for understanding environments and experiences that shape conventional monoracial identities, racially simultaneous identities, or multiracial identities. When investigating an individual's identity, it is important to take into account the geographical history of race, gender, family influences, individual "personality", community, and generation. Any attempt to discuss identity choice will remain at an unsophisticated level, should the diversity apparent within these broad categories of influence not be considered (ROOT; KELLEY, 2003).

\section{Research Strategy}

This research study employed the meta-theoretical paradigm of social constructivism. The methodological paradigm was a qualitative case study and narrative inquiry. The unit of analysis comprised the overall school environment with a particular focus on how "born-free" students constituted, negotiated and represented their identities in educational and social spaces in South Africa.

The research sites for this study comprised of six schools namely, a former White Model C school (English-medium and Afrikaans-medium), a former Indian school, a former Coloured school, a former township school (African) and an inner-city school that has a majority of black African learners. Race, gender and age were the criteria used to select participants for this study. Data capture included a mix of semi-structured interviews and field notes. Semi-structured interviews were conducted with a purposive sample of approximately 8-9 "born-free" students across Grades 8-10 at each of the identified schools. The selection of "born-free" students was dependant on the variety that was present at each of the research sites. In total, 58 students were interviewed in 2015-2016, over a period of eight months. Open-ended questions were posed across five to six broad categories over a duration of 1 to 2 hours. Interviews were recorded and transcribed. Pseudonyms were assigned to research sites and participants, to ensure anonymity and confidentiality.

Cognisance was also taken of the institutional culture and the classroom and school climate. Observations of artefacts such as paintings, decor, photographs, portraits and school magazines provided a sense of the institutional culture of the school, which was captured by means of field notes. Field notes also served to capture the ethos, classroom and school climate and practices of the school. Informal conversations with teachers provided a valuable resource for triangulation of data and were captured as field notes. The emphasis was on experiences of "born-free" students and how they tried to negotiate a balance between establishing 
relationships with other cultures on the one hand, and simultaneously maintaining what they perceived to be their own ethnic identity and cultural characteristics, on the other.

Inductive thematic analysis/qualitative content analysis was used to identify patterns or themes within the qualitative data (JAVADO; ZAREA, 2016; MAYRING, 2000). Data was coded by means of open coding and continuously modified by the researcher's treatment of the data "to accommodate new data and new insights about those data" (SANDELOWSKI, 2000, p. 338). The process was reflexive and interactive and yielded extensive codes and themes, which were further analysed to identify data related to key concepts in the research question, theoretical frameworks, and literature review (MILES; HUBERMAN, 1994). The organization of codes and themes into higher levels of categories within and across the interviews, observations, and other sources of data required multiple readings of the data (MERRIAM, 1998).

Quality measures of this study in terms of research rigour were met by means of trustworthiness of the study namely, transferability, credibility, dependability and confirmability and authenticity. Transferability refers to the scope and the restrictions to which findings of this research can be applied. Credibility of the research findings included the purposeful sampling of the research participant, the sampling of the research site and the application of appropriate data gathering strategies (BUTLER-KISBER, 2010). Dependability was achieved by a process known as auditing. The audit trail procedure can also be valuable when verifying confirmability (SEALE, 2002). The authenticity of this study rests in the "faithful reconstruction of the participant's multiple perceptions" (MCMILLAN; SCHUMACHER, 2001, p. 415). The Ethics Committee at the Faculty of Education granted approval for this study.

\section{Findings}

\subsection{The politics of identity defined by geographical contours of apartheid}

Identities of these students seemed to be shaped politically by the enduring legacies and geographical contours of apartheid. At a first glance the "bornfree" generation, like most South Africans today, seemed proud to be "South African". A closer look, however, revealed complexities. Such complexities extend to the "born frees" view of democracy as compared to apartheid, and the enduring memory that "born frees" acquire through "knowledge in the blood" (JANSEN, 2009). 
South Africa is a more egalitarian society than during apartheid, but race is as salient a factor in determining identity as ever. One student identified as a "white girl in a Black society". Racial identity seems to go hand in hand with a strong South African identity. This study found that black South Africans were far more likely to see themselves as South African when compared with white, Indian or Coloured counterparts. "I am a South African. I live in Attridgeville" (Temba). Some white, Indian and Coloured students identified in terms of apartheid classifications, "A Coloured girl - born as a Coloured girl, live within my region and that is who I am" (Gizelle). "I live and go to a school in an 'Indian area'. I am classified as an Indian. I know this because when we have to fill in some forms I have to put a cross next to Indian. So I guess I am Indian" (Malini).

Others added the adjective South African but did not drop their racial category,

South African, Coloured. I say this is who I am because in our country we are put into groups and classified as a certain race. I live in a coloured community which makes me suppose that's who I am. And due to my skin colour of course (Anton).

\subsection{Shaped by the past: The historical legacy of apartheid}

The hues and contours of democratic South Africa still seem to be shaped by the historical legacy of apartheid. Some citizens have attempted to embrace those of every nationality and race as fellow South Africans; however, the mind-set of race superiority and rights of many others remain unchanged. Hence, two decades into democracy, these students who were born in democratic South Africa still identify in terms of the legacy of apartheid.

I am a young black woman who is right at the bottom of the hierarchy in society. Odds are already stacked against me because I am black but to make it even worse I am a black woman. So I identify as a young black woman who is trying to make it in society but is struggling because of stereotypes and privilege (Andile).

In a country like SA where there are many races, there is unfortunately races that are more superior than others and as a black person I find myself right at the bottom of the list. I face on a daily basis institutional racism, racism and other challenges that make me an underprivileged hated black person (Bongani). 
A young Indian woman who is still hampered by the reigns of apartheid and acts of racism - because it is who I see myself as. I am still hampered by another society's opinions and labels (Perusha).

Muslim by religion, Indian by categorisation. My ancestors are from Pakistan but in South Africa I am labelled as Indian (Ahmed).

\subsection{Psychological bondage: hyphenated identities}

Currently in South Africa, where de jure apartheid no longer exists, the presence or absence of memory suggests that apartheid has, above all, a psychological impact. One is free or not free in one's own mind. Although born in democratic South Africa, responses from some of the participants reflected their inner psychological struggle in terms of identification. For some it seemed to be a question of their loyalty to culture or nation. They seemed to adopt a hyphenated identity, fusing the geographical location with their cultural origins. For example, "A South African-Indian"; "South African-Coloured"; "South African-Muslim" and "White-South African".

One student identified in terms of psychosocial passing "I am a Coloured on paper but in society to others I am identified as Indian". This student adorned a mask of identity and seemed to be trapped in the psychological bondage of perceived superiority. Another student identified as an "African citizen - White Afrikaans speaking". The inherent juxtaposition of African and White clearly depicts this student's struggle with identification. During apartheid the term "African" was mostly used as derogatory and referred to indigenous Black South Africans. Many white Afrikaans-speaking people disassociated themselves from this term. Perhaps this is the juxtaposition required for the emergence of new identities? It must be noted that none of the Black students identified in terms of a hyphenated identity. The identified either as "Black" or as "South African".

\subsection{Personality traits, characteristics and gender}

Black students in mainly mono-racial schools identified overwhelmingly in terms of personality traits, characteristics and by name for example "My name is Lwazi. I have dark brown eyes and I am dark-skinned and soft-spoken". There seemed to be an aversion to identifying in terms of race, ethnicity, religion and so forth. In contrast, at former Model $\mathrm{C}$ schools that now catered to students from all race groups, it seemed that there was a need to distinguish themselves from other racial categories and they thus identified as for example, "Black African female"; "Black male". Ethnicity and religion did not feature in their identification. Some 
students identified only in terms of gender, "a young woman in South Africa" and "a South African, feminist".

\subsection{Ancestral influence}

Ancestry seemed to play a vital role in the way some students chose to identify. For example, "White South African but only because that is what I have been told I was, since my ancestral roots come from Europe and English is my home language" (Julia). "An Indian I say this because of my ancestors and because that's what I've been told by my parents. I also follow all Indian traditions and customs. My name is also Indian in origin" (Shanthi). "Coloured, mixed race I've been identified as a mixed race child because of how my background of my family is and I would say that I am because it has been passed down through our family, generation after generation" (Cecil).

\subsection{Challenging societal labels and stereotypes with self-imposed identities}

It was refreshing to note that some students disassociated their identity from societal classifications and stereotypes. They took on self-imposed identities, for example in terms of a simple yet profound philosophical identity, "I identify as an individual who occupies space" (Jonathan). Another student emphasised capabilities and interests,

I identify as a young woman, an opportunist who believes that my identity should not be limited to my race and gender but to my capabilities and interests. I say this because living in a country where regardless of the wide diversity, people still chose to limit their identity to the stereotypes behind their races. I believe that because times have changed and are still changing, I can step out of that and grab everything with both hands and use it to my advantage. (Rakgadi)

Many identified in terms of technology, for example, "I identify as a teen who just like others in the world is self-centred, keeps things to myself, is always busy on my phone - mostly social networking. I am a global citizen and I try my best to achieve excellently in school, but with huge boredom of working hard" (Santosh).

One student seemed to be a realist and identified as:

a young South African girl born after a very tough time in our country. I am part of the people who were born to make a difference in our 
country using the supposed "freedom" that I possess. I say this is who I am because I can't exactly call myself "born-free". Our country has not reached that level of development whereby we can proudly call ourselves free from any form of oppression (Shavani).

Another student displayed her aversion to racial categories by identifying in terms of physical appearance, as a "young dark-skinned South African woman" (Zama).

\section{7 "Born-free" identities}

Of the 58 students, only two students identified as "born-free",

I identify as a "born-free". One of the lucky ones that were born after the apartheid era. The lucky one that never experienced torture, violence and inequality. The lucky one that is able to go wherever, whenever and however I want. I say this because I am free. Free to be who I want to be, free to do what I want. I have my freedom of speech. I am free to express my feelings, my emotions. Free to be me without being judged (Rabada).

I identify as a person who is "born-free" in South Africa; a person who has rights and on the other side responsibilities (Moosa).

\section{Discussion and Analysis}

The different ways in which these students identified allows for an understanding of the environments, the contexts and the experiences that shape conventional mono-racial identities, racially simultaneous identities, or multiracial identities. With the designation "born frees", it is easy to assume that the identity of this generation of students is obvious and freely crafted. However, this assumption is far from the truth. Identities of these students seemed to be framed within the political, geographical and historical contexts and shaped by the enduring legacies of apartheid. Self and geography were shaped both by institutional realities and the "situatedness" of identity (NORGAARD, 2015).

Findings seem to indicate that "born frees" seemed to be seeking an identity even as the label "born free" was thrust upon them. The data revealed a few distinctive elements of the struggle that "born frees" encounter in constructing, negotiating and representing their identities. The current political freedom experienced by "born frees" is but one dimension of a larger dynamic of psychological freedom and bondage. Some "born-frees" were trapped in a state 
of "in-betweeness" as represented by the contours of the hyphen. Privilege and power seemed to constrain what freedom there is, and both have their roots in the geographical contours of apartheid that currently still persists. Two decades into democracy, the "situatedness" of identities and racial divides, is still apparent in South African society. Identities of the majority of these students seemed to be viewed through contextual macro-lenses of gender, class, and regional history of race, which filtered the meanings of situations and experiences to which they were exposed.

The fact that all the participants at a mono-racial school in the township identified in terms of personality traits and characteristics can be interpreted in two ways. First, since they were all "Black" students at the school, they identified as a collective i.e. Black. There seemed to be no need for them to distinguish themselves from other "Blacks" and hence the emphasis on personality traits and characteristics. Alternatively, could it be that the poor circumstances in which they found themselves warranted a need to reject the racial categorisation of "Black", which in their minds may still hold undertones of the oppressed?

Genealogy also featured strongly in the way some students identified, mainly because this is what they were told and what had been passed down through the generations. Identities of these students seemed to be viewed through the microlenses of inherited influences (e.g. given names, languages spoken in the home, phenotype, cultural values, sexual orientation), traits (e.g. temperament, talents, coping skills), and social environments (e.g. home, school, work) which filter the meaning of daily experiences (ROOT, 1998). Jansen (2009) argues that knowledge is "embedded in the emotional, psychic, spiritual, social, economic, political, and psychological lives of a community" and uses the imagery of "blood" to invoke a life or death issue and to reveal just how deep knowledge is embedded in the individual. However, it does not mean that "through the transfusion of new knowledge the authority of received knowledge cannot be overcome", as blood transfusion is inherently tasked with "change" (JANSEN, 2009).

For the majority of the students in this study, identity seemed to be imposed on them by external factors, to which they silently and unquestioningly acquiesced. There seemed to be a lack of student agency in the formation of their identities. However, despite the persistent geography of apartheid, designed to thwart the shaping of identities, the data revealed the emergence of new identities and the discovery of agency. Some students seemed to be stepping out of the narrow confines of South African societal stereotypes by imposing self-identities related 
to globalisation and social networking. The profound philosophical identification of an "individual who occupies space" by a 14 year old, is illustrative of the shedding of historical, political, social and psychological bondage and points to a more scientifically-oriented identity. This student could be situated anywhere in the world. Another student found the categories of race and gender limiting and wanted to be identified in terms of capabilities and interests. Perhaps her identity as a young woman has already worked against her in a patriarchal society? The response "I can't exactly call myself "born-free". Our country has not reached that level of development whereby we can proudly call ourselves free from any form of oppression" by a 15 year old student, indicates that these students are not only well aware of the social and political dynamics of the country, but are also beginning to question externally imposed identities.

The fact that only two students identified as "born-free" is indicative of the fallacy of the term "born-free". The invested hope in the "born-frees" to build the "Rainbow Nation" seems to stem from the fact that their upbringing occurred in a different time and context from previous generations of South Africans, and their right to cultural freedom that enables them to define themselves. Yet, South Africa imposes the identity of "born-free" on them. Ironic, is it not?

\section{Conclusion}

What conclusion can we glean from this data? We learn that the "born free" generation as a whole mirrors the South African general population. The generation's demographic diversity seems to extend towards many competing views of identity. At the aggregate level, at least, "born free" South Africans do not possess distinctive views on their generations" identity. Racial identity by contrast still plays a large role. Some "born frees" expressed optimism with the freedom their identity provides, while others felt constrained by the enduring legacies and memories of the past. Although "born frees" themselves did not live through apartheid, the physical legacies of apartheid -such as geographical segregation- served as a daily reminder of its presence. In this regard, "born free" South Africans are not as different as their struggle pre-apartheid counterparts as one might think.

It is hoped that through the construction of narratives of experience, their lived and told stories will unfold and the diversity of their identities that will be negotiated with others within personal, historical and situational contexts will be revealed. The study of "born-free" students" lives from their perspective, in which they actively and socially develop their identities, not only provides a lens through which they can be understood as shifting constructions of identity, but allows 
them to rethink who they are and have become and what influence power relations and the social, historical and political contexts have had in promoting or negating their sense of self. It also allows for the exploration of what implications these shifting constructions of identities hold for educational change. 


\section{Retirando das caixas os "nascidos livres": a liberdade de escolher as identidades}

\section{Resumo}

Este estudo de caso qualitativo como os estudantes "nascidos livres" negociam e representam suas identidades na África do Sul vinte anos após a democracia. O paradigma metateórico do construtivismo social e a metodologia da pesquisa narrativa foram utilizados. Os dados foram obtidos a partir de um conjunto de entrevistas semi-estruturadas e de notas de campo. A análise indutiva temática foi usada para a interpretação dos dados. Os resultados revelam que a diversidade demográfica dos alunos "nascidos livres" parece apontar para visões contraditórias sobre a identidade. Estudantes "nascidos livres" não possuíam visões específicas sobre a identidade de sua geração. A identidade racial ainda aparece como central. Alguns estudantes "nascidos livres" expressaram otimismos com a liberdade que suas identidades lhes provêm, enquanto outros ainda se sentiram constrangidos pela herança persistente do apartheird, transmitida pelo conhecimento " de sangue". Embora os estudantes "nascidos livres" não tenham vivenciado o apartheid, os aspectos fisicos persistentes-como, por exemplo, as fronteiras geográficas - servem, para eles, como lembranças vivas de sua presença. Além de conscientes da dinâmica social e política do país, estes estudantes também começam a problematizar identidades que lhes são externamente impostas.

Palavras-chave: estudantes "nascidos livres"; conhecimento de sangue; identidade; fronteiras geográficas; herança histórica; justiça juvenil.

\section{Desempacando a los "nacidos libres": la libertad de elegir identidades}

\section{Resumen}

Este estudio de caso cualitativo investiga cómo estudiantes "nacidos libres" negocian y representan sus identidades en Sudáfrica veinte años después de la llegada de la democracia. Se utilizó el paradigma metateórico del constructivismo social y la metodología de la investigación narrativa. Los datos se obtuvieron de un conjunto de entrevistas semiestructuradas y notas de campo. El análisis inductivo temático se utilizó para interpretar los datos. Los resultados demuestran que la diversidad demográfica de los estudiantes "nacidos libres" parece apuntar a visiones contradictorias sobre la identidad. Los estudiantes "nacidos libres" no poseen visiones especificas sobre la identidad de su generación. La identidad racial sigue apareciendo como central. Algunos estudiantes "nacidos libres "expresaron optimismo con la libertad que sus identidades les proporcionaban, mientras que otros seguian avergonzados por la persistente herencia del Apartheird, transmitido por el conocimiento "de la sangre". Aunque los estudiantes "nacidos libres" no experimentaron el apartheid, los aspectos fisicos persistentes - como los límites geográficos - sirven, para ellos, como recuerdos vivos de su presencia. Además de ser conscientes de la dinámica social y política del país, estos estudiantes también comienzan a problematizar las identidades que se les imponen externamente.

Palabras clave: Estudiantes "nacidos libres". Conocimiento de la sangre. Identidad. Limites geográficos. Patrimonio histórico. Justicia para los jóvenes. 


\section{References}

ALVESSON, M.; ASCHCRAFT, K. L.; THOMAS, R. Identity matters: reflections on the construction of identity scholarship in organization studies. Organization, v. 15, n. 1, p. 5-28, 2008. https://doi.org/10.1177/1350508407084426

BARTH, F. Ethnic groups and boundaries: the social organization of culture difference. London: Allen and Unwin, 1969.

BARTH, F. Process and form in social life. London: Routledge and Kegan Paul, 1981. (Collected Essays of Fredrik Barth, 1).

BERRY, J. W. et al. Immigrant youth: acculturation, identity and adaptation. Applied Psychology: An International Review, v. 55, n. 3, p. 303-3, 2006. https://doi.org/10.1111/j.1464-0597.2006.00256.x

BRIEGER, S. A. Social identity and environmental concern: the importance of contextual effects. Environment and Behaviour, Feb. 2018. https://doi.org/10.1177/0013916518756988

BUTLER-KISBER, L. Qualitative inquiry: thematic, narrative and arts-informed perspectives. Washington, DC: Sage, 2010.

CAWE, Z. N. The born-free fallacy. Stellenbosch: BonFire, 2014. Available at: <http://www.bonfiire.com/stellenbosch/2014/03/the-born-free-fallacy/>. Accessed on: 2017 May 5

COHEN, R. Ethnicity: problem and focus in anthropology. Annual Raview of Anthropology, v. 7, p. 379-403, 1978.

https://doi.org/10.1146/annurev.an.07.100178.002115

COHEN, E. H. Components and symbols of ethnic identity: a case study in informal education and identity formation in diaspora. Applied Psychology, v. 53, n. 1, p. 87-112, 2004. https://doi.org/10.1111/j.1464-0597.2004.00162.x

CORNWELL, S. That's the story of our life. In: SPICKARD, P.; BURROUGHS W. J. (Eds.). We are a people: narrative and multiplicity in constructing ethnic identity. Philadelphia, PA: Temple University, 2000. p. 41-57.

EPSTEIN, A. L. Ethos and identity: three studies in ethnicity. London: Tavistock, 1978.

ERICKSON, E. Identity youth and crisis. New York, NY: Norton, 1968. 
FEARON, J. D. What is identity: as we now use the word? Palo Alto, CA: Stanford University, 1999.

FORSYTH, H. An identity as Pākehā. Alternataive: An International Journal of Indigenous Peoples, v. 14, n. 1, p. 73-80, 2018. https://doi.org/10.1177/1177180117752479

FRENCH, S. E.; SIEDMAN, E.; ALLEN, L. et al. The development of ethnic identity during adolescence. Developmental Psychology, v. 42, n. 1, p. 1-10, 2006. https://doi.org/10.1037/0012-1649.42.1.1

GLAZER, N.; MOYNIHAN, D. P. Beyond the melting pot: the negroes, puerto ricans, jews, italians and irish of New York City. Cambridge, MA: THUS, 1963. (Harvard - MIT Joint Center for Urban Studies).

HALL, S. New ethnicities. In: MORLEY, D.; KUAN-HSING, C. (Eds.). Stuart Hall: critical dialogues in cultural studies. London: Routledge, 1996a. p. 1-22

HALL, S. Old and new identities, old and new ethnicities. In: KING, A. D. (Ed.). Culture globalization and the world-system. London: Macmillan, 1993. p. 41-68.

HALL, S. What is 'black' in black popular culture? In: MORLEY, D.; KUAN-HSING, C. (Eds.), Stuart Hall: critical dialogues in cultural studies. London: Routledge, 1996b. p. 468-78

ISRAELITE, N.; OLIVER, J.; GOLDSTEIN, G. Hard of hearing adolescents and identity construction: influences of school experiences, peers and teachers. Journal of Deaf Studies and Deaf Education, v. 7, n. 2, p. 134-48, 2002. https://doi.org/10.1093/deafed/7.2.134

JANSEN, J. D. Knowledge in the blood: confronting race and the apartheid past. Palo Alto, CA: Stanford University, 2009.

JAVADO, M.; ZAREA, M. Understanding thematic analysis and its pitfalls. Journal of Client Care, v. 1, n. 1, p. 33-9, 2016. https://doi.org/10.15412/J.JCC.02010107

JENSEN, A. Coming of age in a multicultural world: globalization and adolescent cultural identity formation. Applied Developmental Science, v. 7, n. 3, p. 189-96, 2003. https://doi.org/10.1207/S1532480XADS0703_10 
MAIMELA, D. Born frees do not exist. Mail \& Guardian, Jan. 8, 2014.

MARCIA, J. E. Development and validation of ego identity status. Journal of Personality and Social Psychology, v. 3, n. 5, p. 551-8, 1966. https://doi.org/10.1037/h0023281

MARCIA, J. E. Identity in adolescence. In: ADELSON. J. (Ed.). Handbook of adolescent psychology. New York, NY: John Wiley and Sons, p. 159-87, 1980.

MAYRING, P. Qualitative content analysis. Forum: Qualitative Social Research, v. 1, n. 2, p. 1-10, 2000. https://doi.org/10.17169/fqs-1.2.1089

MCMILLAN, J.; SCHUMACHER, S. Research in education: a conceptual introduction. New York, NY: Longman, 2001.

MEEUS, W. et al. Patterns of adolescent identity development: review of literature and longitudinal analysis. Developmental Reviews, v. 19, n. 4, p. 449-61, 1999. https://doi.org/10.1006/drev.1999.0483

MERRIAM, S. B. Qualitative research and case study applications in education. San Francisco, CA: Jossey-Bass, 1998.

MILES, M. B.; HUBERMAN, A. M. Qualitative data analysis: an expanded sourcebook. 2. ed. London: Sage, 1994.

NORGAARD, S. Rainbow junction: South Africa's born free generation and the future of democracy. Stanford Digital Repository, 2015. Available at: $<$ http://purl.stanford.edu/vv235mx1028>. Accessed on: 2017 Apr. 18.

OKAMURA, J. Y. Situational ethnicity. Ethnic and Racial Studies, v. 4, n. 4, p. 452-65, Oct. 1981. https://doi.org/10.1080/01419870.1981.9993351

OLIVEIRA, R. C. Identidade, etnia e estrutura social. São Paulo, SP: Pioneira, 1976.

ONORATO, R. S.; TURNER, J. C. Fluidity in the self-concept: the shift from personal to social identity. European Journal of Social Psychology, v. 34, n. 3, p. 257-78, 2004. https://doi.org/10.1002/ejsp.195

PARHAM, T. A. Cycles of psychological nigrescence. The

Counselling Psychologist, v. 17, n. 2, p. 187-226, 1989.

https://doi.org/10.1177/0011000089172001 
PHINNEY, J. et al. Ethnic identity immigration, and well-being: an interactional perspective. Journal of Social Issues, v. 57, n. 3, p. 493-510, 2001. https://doi.org/10.1111/0022-4537.00225

ROOT, M. P. P. Experiences and processes affecting racial identity development: preliminary results from the biracial sibling project. Cultural Diversity and Mental Health, v. 4, n. 3, p. 237-47, 1998. https://doi.org/10.1037/1099-9809.4.3.237

ROOT, M. P. P. Racial identity development and persons of mixed race heritage. In: ROOT, M. P. P.; KELLY, M. (Eds.). Multiracial child resource book: living complex identities. Seattle, WA: MAVIN Foundation, 2003. p. 34-41

ROOT, M. P. P.; KELLEY, M. Issues and experiences of racially mixed people. In: ROOT, M. P. P.; KELLY, M. (Eds.). The multiracial child resource book: living complex identities. Seattle, WA: Mavin Foundation, 2003. p. 132-4.

SANDELOWSKI, M. Focus on research methods: whatever happened to qualitative description? Research in Nursing and Health, v. 23, n. 4, p. 33440, 2000. https://doi.org/10.1002/1098-240X(200008)23:4<334::AID-NUR9 $>3.0 . \mathrm{CO} ; 2-\mathrm{G}$

SCHWARTZ, S. J. et al. Identity development in immigrant youth: a multilevel contextual perspective. European Psychologist, v. 23, n. 4, p. 336-49, 2017. https://doi.org/10.1027/1016-9040/a000335

SEALE, C. The quality of qualitative research. London: Sage, 2002.

STETS, J. E.; BURKE, P. J. Identity theory and social identity theory. Social Psychology Quarterly, v. 63, n. 3, p. 224-37, 2000.

SUAREZ-OROZCO, C.; SUAREZ-OROZCO, M. Learning in a new land: immigrant students in american society. London: Harvard University, 2008.

TAJFEL, H. Social identity and intergroup relations. Cambridge: Cambridge University, 2010.

TEIXEIRA, M. D. P. Democratizing the access to college education: brazilian race/color classification in affirmative action's debate. Ensaio: Avaliação e Políticas Públicas em Educação, v. 26, n. 100, p. 595-618, 2018. https://doi.org/10.1590/s0104-40362018002601768 
VANDEYAR, S. Educational and social cultural experience of immigrant students in South African schools. Educational Inquiry, v. 1, n. 4, p. 347-65, 2010. https://doi.org/10.3402/edui.v1i4.21950

WIRTH, L. The problem of minority groups. In: PARSONS, T.; SHILS, E.; NAEGELE, K. D. et. al. Theories of society: foundations of modern sociological theory. New York, NY: Free, 1961. p. 301-5

YIP, T. Ethnic/racial identity: a double-edged sword? associations with discrimination and psychological outcomes. Current Directions in Psychological Science, v. 27, n. 3, p. 170-5, 2018. https://doi.org/10.1177/0963721417739348

YIP, T. Everyday experiences of ethnic and racial identity among adolescents and young adults. In: QUINTANA, S. M.; McKOWN, C. (Eds.). Handbook of race, racism and the developing child. Hobekon: Wiley \& Sons, 2008. p. 182-202.

YUVAL-DAVIS, N. Theorizing identity: beyond the 'us' and 'them' dichotomy. Patterns of Prejudice, v. 44, n. 3, p. 261-80, 2010. https://doi.org/10.1080/0031322X.2010.489736

\section{Informação da autora}

Prof Saloshna Vandeyar: Director: Centre for Diversity and Social Cohesion Full Professor: Department of Humanities Education Chair: Research Committee Faculty of Education, University of Pretoria, South Africa Contato: saloshna.vandeyar@up.ac.za

(iD) https://orcid.org/0000-0003-0195-6330 